\title{
Determinan Kejadian Infeksi Saluran Pernapasan Akut (ISPA) pada Balita
}

\author{
Ervi Imaniyah ${ }^{1}$, Irma Jayatmi ${ }^{2}$ \\ ${ }^{1,2}$ Program Studi Kebidanan Program Sarjana Terapan Sekolah Tinggi Ilmu Kesehatan Indonesia Maju \\ Jl. Harapan Nomor 50, Lenteng Agung - Jakarta Selatan 12610, Indonesia Telp: (021) 78894043 \\ Email:1 erviimaniyah@gmail.com; ${ }^{2}$ irma.jayatmi@ @stikim.ac.id
}

\begin{abstract}
Abstrak
Penyakit ISPA merupakan salah satu penyebab kematian utama pada bayi dan balita di negara berkembang. Tujuan umum penelitian ini adalah untuk mengetahui hubungan antara gizi kurang, BBLR dan kurangnya imunisasi campak dengan kejadian ISPA pada balita di Puskesmas Kecamatan Cilandak tahun 2018. Penelitian ini merupakan penelitian kuantitatif yang menggunakan metode survei analitik dengan pendekatan Cross Sectional. Pengambilan sampel pada penelitian ini menggunakan teknik accidental sampling. Data diperoleh dari data primer melalui wawancara dan observasi dengan menggunakan kuesioner sebagai instrumen penelitian. Hasil penelitian ini menunjukkan bahwa dari 97 responden sebanyak 45 balita $(46,4 \%)$ mengalami ISPA, 7 balita $(7,2 \%)$ mengalami gizi kurang, 6 balita $(6,2 \%)$ memiliki riwayat BBLR, dan $16(16,5 \%)$ kurang mendapatkan imunisasi campak. Berdasarkan hasil analisis bivariat, nilai P-value gizi kurang=0,047, artinya ada hubungan antara gizi kurang dengan kejadian ISPA, nilai P-value $\mathrm{BBLR}=0,093$, artinya tidak ada hubungan antara BBLR dengan kejadian ISPA dan nilai P-value kurangnya imunisasi campak=0,015, artinya ada hubungan antara kurangnya imunisasi campak dengan kejadian ISPA. Kesimpulannya adalah terdapat dua variabel bebas yang berhubungan dengan kejadian ISPA, yaitu gizi kurang dan kurangnya imunisasi campak. Sarannya adalah bagi orang tua yang memiliki anak yang menderita ISPA diharapkan dapat meningkatkan pengetahuan tentang ISPA serta faktor-faktor penyebabnya.
\end{abstract}

Kata Kunci : : BBLR, Gizi Kurang, Kurangnya Imunisasi Campak

\begin{abstract}
ARI is one of causes the death in infants and toddlers in developing countries. The purpose of this studyies are to determine the correlation of malnutrition, $L B W$ and incomplete measles immunization with ARI in toddlers at Puskesmas Kecamatan Cilandak in 2018. This study was a quantitative study using analytical survey methods with a cross sectional approach. Sampling in this study used accidental sampling technique. The results of this study indicate that 97 respondents were 45 toddlers had ARI, 7 toddlers had malnutrition, 6 toddlers had a history of $L B W$, and 16 incomplete to get measles immunization. Based on the results of bivariate analysis, the value of $P$-value of malnutrition=0.047, it means that there was a correlation between malnutrition and the ARI, $P$-value of $L B W=0.093$, it means that there was not correlation between $L B W$ and ARI and $P$-value, the incomplete measles immunization $=0.015$, it means that there was a correlation between the incomplite measles immunization and the incidence of ARI. The conclusion is there are two independent variables related with the ARI, malnutrition and incomplete measles immunization. The suggestion is especially for parents who have children suffer of ARI, hopefully they will can be increase their knowledge about ARI and its causes.
\end{abstract}

Keywords: LBW, Malnutrition, Incomplete Measles Immunization. 


\section{Pendahuluan}

Infeksi saluran pernapasan akut (ISPA) adalah penyakit saluran pernapasan atas atau bawah, biasanya menular, yang dapat menimbulkan berbagai spektrum penyakit yang berkisar dari penyakit tanpa gejala atau infeksi ringan sampai penyakit yang parah dan mematikan, tergantung pada patogen penyebabnya, faktor lingkungan dan faktor penjamu. Namun demikian, sering juga ISPA didefinisikan sebagai saluran pernapasan akut yang disebabkan oleh agen infeksius yang ditularkan dari manusia ke manusia. Timbulnya gejala biasanya cepat, yaitu dalam waktu beberapa jam sampai beberapa hari. Gejalanya meliputi demam, batuk dan sering nyeri tenggorok, coryza (pilek), sesak napas, mengik, atau kesulitan bernapas.

Infeksi saluran pernapasan akut atau sering disebut sebagai ISPA adalah terjadinya infeksi yang parah pada bagian sinus, tenggorokan, saluran udara, atau paru-paru. Infeksi yang terjadi lebih sering disebabkan oleh virus meski bakteri juga bisa menyebabkan kondisi ini. ${ }^{2}$

Pneumonia adalah pembunuh utama balita di dunia, lebih banyak dibanding dengan gabungan penyakit AIDS, malaria dan campak. Di dunia setiap tahun diperkirakan lebih dari 2 juta Balita meninggal karena Pneumonia (1 Balita/20 detik) dari 9 juta total kematian Balita. Diantara 5 kematian Balita, 1 di antaranya disebabkan oleh pneumonia. Bahkan karena besarnya kematian pneumonia ini, pneumonia disebut sebagai "pandemi yang terlupakan" atau "the forgotten pandemic". Namun, tidak banyak perhatian terhadap penyakit ini, sehingga pneumonia disebut juga pembunuh Balita yang terlupakan atau "the forgotten killer of children" (Unicef/WHO 2006, WPD 2011). Di negara berkembang 60\% kasus pneumonia disebabkan oleh bakteri. ${ }^{1}$

Infeksi Saluran Pernapasan Akut (ISPA) merupakan penyakit yang sering terjadi pada anak. Insiden menurut kelompok umur Balita diperkirakan 0,29 episode per anak/tahun di negara berkembang dan 0,05 episode per anak/tahun di negara maju. Ini menunjukkan bahwa terdapat 156 juta episode baru di dunia per tahun dimana 151 juta episode $(96,7 \%)$ terjadi di negara berkembang. Kasus terbanyak terjadi di India (43 juta), China (21 juta) dan Pakistan (10juta) dan
Bangladesh, Indonesia, Nigeria masing-masing 6 juta episode. Dari semua kasus yang terjadi di masyarakat, $7-13 \%$ kasus berat dan memerlukan perawatan rumah sakit. Episode batuk-pilek pada Balita di Indonesia diperkirakan $2-3$ kali per tahun (Rudan et al Bulletin WHO 2008). ISPA merupakan salah satu penyebab utama kunjungan pasien di Puskesmas (40\%-60\%) dan rumah sakit (15\%$30 \%)^{3}$

Penyakit ISPA (Infeksi Saluran Pernafasan Akut) merupakan salah satu penyebab kematian utama pada bayi dan balita di negara berkembang. ISPA di Indonesia merupakan salah satu masalah kesehatan utama karena masih tinggi angka kejadian ISPA terutama pada balita. ISPA merupakan jenis penyakit menular yang biasanya menyerang balita dengan rentan usia kurang dari lima tahun. ${ }^{4}$

Di Indonesia kasus ISPA selalu menempati urutan pertama penyebab $32,1 \%$ kematian bayi pada tahun 2009, serta penyebab 18,2\% kematian pada balita pada tahun 2010 dan 38,8\% tahun 2011. Selain itu ISPA juga sering berada pada daftar 10 penyakit terbanyak di rumah sakit. Berdasarkan data dari P2 program ISPA tahun 2009 cakupan penderita ISPA melampaui target $13,4 \%$, hasil yang diperoleh 18.749 kasus sementara target yang ditetapkan hanya 16.534 kasus. Survey mortalitas yang dilakukan di subdit ISPA tahun 2010 menempatkan ISPA/Pneumonia sebagai penyebab kematian bayi terbesar di Indonesia dengan persentase $22,30 \%$ dari seluruh kematian balita. $^{5}$

Hasil Survei Kesehatan Nasional di Indonesia tahun 2009 menunjukkan bahwa proporsi kematian bayi akibat ISPA masih $28 \%$ artinya bahwa dari 100 bayi meninggal 28 disebabkan oleh penyakit ISPA dan terutama 80\% kasus kematian ISPA pada balita adalah akibat Pneumonia. Angka kematian balita akibat pneumonia pada akhir tahun 2008 di perkirakan sekitar 4,9/1000 balita, berarti terdapat 140.000 balita yang meninggal setiap tahunnya akibat pneumonia, atau rata-rata 1 anak balita Indonesia meninggal akibat pneumonia setiap 5 menit. $^{5}$

Penyakit menular yang dikumpulkan dalam Riskesdas 2013 berdasarkan media/cara penularan yaitu: melalui udara (Infeksi Saluran Pernafasan Akut/ISPA, pneumonia, dan TB 
paru); melalui makanan, air dan lainnya (hepatitis, diare); dan melalui vektor (malaria). Period prevalence Infeksi Saluran Pernafasan Akut (ISPA) berdasarkan diagnosis tenaga kesehatan dan keluhan penduduk Indonesia adalah 25\%. Penyakit ini lebih banyak dialami pada kelompok penduduk dengan kuintil indeks kepemilikan terbawah dan menengah bawah. Tiga kelompok umur yang memiliki insiden ISPA terbanyak yaitu $1-4$ tahun $(41,9 \%),<1$ tahun $(35,2 \%)$ dan $5-14$ tahun $(27,8 \%)$. Pada balita $0-11$ bulan $(13,6 \%), 12$ - 23 bulan (21,7\%), $24-35$ bulan (21\%), $36-$ 47 bulan $(18,2 \%)$, dan $48-59$ bulan $(17,9 \%)$. Lima provinsi dengan ISPA tertinggi adalah Nusa Tenggara Timur (41,7\%), Papua $(31,1 \%)$, Aceh $(30,0 \%)$, Nusa Tenggara Barat (28,3\%), dan Jawa Timur (28,3\%). Di DKI Jakarta Period prevalence ISPA berada pada urutan sebelas yaitu sebanyak $25,2 \% .^{6.7}$

ISPA umumnya ditularkan melalui droplet. Namun demikian, pada sebagian patogen ada juga kemungkinan penularan melalui cara lain, seperti melalui kontak dengan tangan atau permukaan yang terkontaminasi. $^{8}$ Faktor risiko yang berkontribusi terhadap insiden ISPA adalah kurangnya pemberian ASI eksklusif, gizi kurang, polusi udara dalam ruangan (indoor air pollution), Berat Badan Lahir Rendah (BBLR), kepadatan penduduk dan kurangnya imunisasi campak. $^{3}$

Pada kasus gizi kurang, individu akan lebih rentan terhadap infeksi akibat menurunnya kekebalan tubuh terhadap invasi patogen. Pertumbuhan yang baik dan status imunologi yang memadai akan menghasilkan tingkat kesehatan yang baik pula. Sebaliknya, pertumbuhan fisik yang terhambat biasanya disertai dengan status imunologi yang rendah sehingga balita mudah terkena penyakit. Berdasarkan hasil pemantauan status gizi (PSG) Tahun 2016, di Indonesia sebanyak $3,4 \%$ balita mempunyai status gizi buruk dan $14,4 \%$ balita mempunyai status gizi kurang. Hasil penelitian yang dilakukan oleh Hadiana (2013) tentang hubungan status gizi terhadap terjadinya ISPA pada balita di Puskesmas Pajang Surakarta menyatakan bahwa ada hubungan antara status gizi terhadap terjadinya ISPA. Selain itu didapatkan nilai ratio prevalensi 27,5 yang artinya bahwa anak yang mengalami gizi kurang berisiko 27,5 kali untuk mengalami ISPA dibanding balita yang mengalami gizi baik. ${ }^{7}$

Salah satu faktor yang mempengaruhi kejadian ISPA adalah Berat Badan Lahir. Seperti yang dikemukakan oleh Daichi (2009), resiko kesakitan hingga resiko kematian pada BBLR cukup tinggi oleh karena adanya gangguan pertumbuhan dan imaturitas organ. Penyebab utama kematian pada BBLR adalah asfiksia, sindroma gangguan pernapasan, infeksi dan komplikasi hipotermia. Pada bayi BBLR, pembentukan zat anti kekebalan kurang sempurna sehingga lebih mudah terkena penyakit infeksi terutama pneumonia dan sakit saluran pernapasan lainnya. Hasil Riskesdas 2013 menunjukkan Persentase BBLR tahun 2013 adalah 10,2\%. Di DKI Jakarta sendiri presentasi BBLR adalah 9\% Menurut jenis pekerjaan, persentase BBLR tertinggi pada anak balita dengan kepala rumah tangga yang tidak bekerja $(11,6 \%)$, sedangkan persentase terendah pada kelompok pekerjaan pegawai $(8,3 \%)$. Hasil penelitian yang dilakukan oleh Aprianingsih Husin (2014) tentang Hubungan BBL dan status imunisasi dengan kejadian ISPA pada balita di Puskesmas Wirobrajan Yogyakarta menyatakan bahwa ada hubungan berat badan lahir dengan kejadian ISPA. ${ }^{9}$

Salah satu pencegahan penyakit ISPA antara lain dengan imunisasi. Pemberian imunisasi sangat diperlukan baik pada anakanak maupun orang dewasa. Imunisasi dilakukan untuk menjaga kekebalan tubuh kita supaya tidak mudah terserang berbagai macam penyakit yang disebabkan oleh virus/bakteri. Imunisasi bermafaat untuk mencegah beberapa jenis penyakit infeksi seperti polio, TBC, difteri, pertusis, tetanus, hepatitis B dan Campak (Depkes RI, 2005). Hasil Riskesdas 2013 menunjukkan cakupan imunisasi campak di Indonesia sebanyak $82,1 \%$, di DKI Jakarta cakupan imunisasi campak sebanyak $85,3 \%$. Hasil penelitian yang dilakukan oleh Lisdianti, Saparwati \& Choiriyah (2015) tentang hubungan status imunisasi terhadap kejadian ISPA pada anak usia Balita di wilayah kerja Puskesmas Pasir Putih Sampit Kalimantan Tengah menyatakan bahwa ada hubungan status imunisasi terhadap kejadian ISPA. Anak yang mendapatkan imunisasi lengkap lebih rendah mengalami kejadian ISPA daripada yang tidak mendapatkan imunisasi lengkap. ${ }^{5}$

Berdasarkan studi pendahuluan yang telah dilakukan oleh penulis di Poli MTBS 
Puskesmas Kecamatan Cilandak pada tanggal 17 April 2018 didapatkan data bahwa jumlah pengunjung Balita di Puskesmas Kecamatan Cilandak selama tahun 2017 adalah sebanyak 9.915 anak. ISPA merupakan kasus penyakit terbanyak, yaitu sebanyak 4.839 anak $(48,8 \%)$. Dari total kasus ISPA, sebanyak 4.336 $(89,6 \%)$ bukan pneumonia dan sisanya 503 $(10,4 \%)$ merupakan pneumonia. Pneumonia adalah pembunuh utama balita di dunia. Selain itu pada tahun 2017 di Kecamatan Cilandak, prevalensi gizi kurang adalah 5\%, kasus BBLR sebanyak $6 \%$ dari angka kelahiran hidup dan cakupan imunisasi campak adalah 93\%.

Tujuan penelitian ini adalah untuk mengetahui hubungan gizi kurang, BBLR dan kurangnya imunisasi campak dengan kejadian ISPA pada Balita di Puskesmas Kecamatan Cilandak tahun 2018.

\section{Metode}

Desain penelitian adalah rancangan penelitian yang terdiri atas beberapa komponen yang menyatu satu sama lain untuk memperoleh data dan/atau fakta dalam rangka menjawab pertanyaan atau masalah penelitian. Penelitian ini merupakan penelitian kuantitatif yang menggunakan metode survei analitik dengan pendekatan Cross Sectional. Penelitian survei adalah penelitian yang dilakukan tanpa melakukan intervensi terhadap subjek penelitian, sehingga disebut penelitian noneksperimen. Metode survei analitik adalah survei atau penelitian yang mencoba menggali bagaimana dan mengapa fenomena kesehatan itu terjadi. Kemudian melakukan analisis dinamika korelasi antara fenomena atau antara faktor risiko dengan faktor efek. Yang dimaksud faktor efek adalah suatu akibat dari adanya faktor risiko, sedangkan faktor risiko adalah suatu fenomena yang mengakibatkan terjadinya efek atau pengaruh. Dalam penelitian cross sectional atau potong silang, variabel sebab atau risiko dan akibat atau kasus yang terjadi pada objek penelitian diukur dan dikumpulkan secara simultan atau dalam waktu yang bersamaan. ${ }^{10.11}$

Dalam Penelitian ini, gizi kurang, BBLR dan kurangnya imunisasi campak adalah suatu faktor risiko untuk terjadinya kejadian ISPA (efek). Dalam penelitian ini, data tentang gizi kurang, BBLR, kurangnya imunisasi campak dan kejadian ISPA dikumpulkan dalam waktu yang bersamaan.
Instrumen penelitian adalah suatu alat yang digunakan untuk mengukur fenomena alam atau sosial yang diamati. Secara spesifik semua fenomena ini disebut variabel penelitian. Instrumen dalam penelitian ini menggunakan kuesioner. Kuesioner dalam penelitian ini berfungsi untuk mengumpulkan data yang diperoleh lewat wawancara dan observasi. Teknik pengukuran variabel-variabel dalam penelitian ini menggunakan standar pengukuran yang baku sehingga tidak perlu dilakukan uji validitas dan uji reliabilitas. ${ }^{12}$

Penelitian ini dilaksanakan pada tanggal 11, 12, 13 dan 16 Juli 2018, bertempat di Puskesmas Kecamatan Cilandak yang beralamat di Jl. Komplek BNI 1946 Kelurahan Cilandak Barat, Kecamatan Cilandak, Kota Administrasi Jakarta Selatan, Provinsi DKI Jakarta. Penelitian ini menggunakan teknik pengambilan data primer yang diambil secara langsung dari responden, dengan menggunakan kuesioner yang diisi sendiri oleh peneliti berdasarkan hasil wawancara dan observasi.

Populasi dalam penelitian ini adalah seluruh anak usia balita yang berkunjung di Puskesmas Kecamatan Cilandak tahun 2018. Pengambilan sampel dalam penelitian dilakukan menggunakan non probability sampling dengan teknik accidental sampling yaitu yaitu teknik penentuan sampel berdasarkan kebetulan, yaitu siapa saja yang secara kebetulan/insidental bertemu dengan peneliti dapat dijadikan sampel. ${ }^{12}$ Dalam penelitian ini, analisis data melalui prosedur bertahap yaitu analisis univariat dan analisis bivariat. Analisis univariat digunakan untuk melihat distribusi frekuensi dari tiap-tiap variabel yaitu kejadian ISPA, gizi kurang, BBLR dan kurangnya imunisasi campak. Sedangkan analisis bivariat menggunakan uji statistik Chi-square dengan komputerisasi SPSS versi 21 . Uji Chi-square $\left(x^{2}\right)$ adalah uji statistik untuk melihat hubungan antara dua variabel yang dikategorikan. Uji ini akan digunakan untuk menguji hubungan antara gizi kurang dengan kejadian ISPA, hubungan antara BBLR dengan kejadian ISPA dan hubungan antara kurangnya imunisasi campak dengan kejadian ISPA. ${ }^{13}$ Cara penyajian data dalam penelitian dilakukan melalui berbagai bentuk. Pada umumnya dikelompokkan menjadi tiga, yakni penyajian dalam bentuk teks (textular), penyajian dalam bentuk tabel, 
dan penyajian dalam bentuk grafik. Dalam penelitian ini, bentuk penyajian datanya adalah tabel dan teks. ${ }^{11}$

\section{Hasil}

Hasil penelitian menunjukan adanya hubungan antara gizi kurang dan kurangnya imunisasi campak dengan kejadian ISPA pada Balita di Puskesmas Kecamatan Cilandak Tahun 2018 serta tidak adanya hubungan antara BBLR dengan kejadian ISPA pada Balita di Puskesmas Kecamatan Cilandak Tahun 2018 . Hasil dari pengolahan data tersebut dapat dilihat dari hasil output SPSS dengan menggunakan uji chi square, karena penelitian ini menggunakan table $2 \times 2$ dan ada nilai expected count $<5$ maka hasil yang dibaca yaitu nilai Fisher's Exact Test.

Tabel 1: Distribusi Frekuensi Gizi Kurang, BBLR dan Kurangnya Imunisasi Campak dengan Kejadian ISPA pada Balita di Puskesmas Kecamatan Cilandak Tahun 2018

\begin{tabular}{lll}
\hline Variabel & Frekuensi & Presentase \\
\hline ISPA & & \\
Ya & 45 & 46,4 \\
Tidak & 52 & 53,6 \\
Gizi Kurang & & \\
Ya & 7 & 7,2 \\
Tidak & 90 & 92,8 \\
BBLR & & \\
Ya & 6 & 6,2 \\
Tidak & 91 & 93,8 \\
Kurang & & \\
Imunisasi & & \\
Campak & 16 & 16,5 \\
Ya & 81 & 83,5 \\
Tidak & & \\
\hline
\end{tabular}

Sumber: Hasil analisis SPSS versi 21 Tahun 2018

Berdasarkan tabel 1 dapat diketahui bahwa dari 97 balita di Puskesmas Kecamatan Cilandak, sebanyak 52 balita $(53,6 \%)$ tidak mengalami ISPA, 90 balita $(92,8 \%)$ tidak mengalami gizi kurang, 91 balita $(93,8 \%)$ tidak memiliki riwayat BBLR dan 81 balita $(83,5 \%)$ memiliki status imunisasi campak yang lengkap.

Berdasarkan tabel 2 terlihat bahwa dari 7 balita yang memiliki status gizi kurang, sebanyak 6 balita $(6,2 \%)$ mengalami ISPA dan hanya 1 balita (1\%) tidak mengalami ISPA. Dari 90 balita yang tidak memiliki status gizi kurang, sebanyak 39 balita $(40,2 \%)$ mengalami ISPA dan 51 balita $(52,6 \%)$ tidak mengalami ISPA. Dari hasil uji statistik, diketahui bahwa nilai $\mathrm{p}$ value $=0,047$ yang berarti $p<0,05$, sehingga menunjukkan hasil yang signifikan. Dengan demikian dapat kita simpulkan bahwa secara statistik terdapat hubungan antara gizi kurang dengan kejadian ISPA pada Balita di Puskesmas Kecamatan Cilandak.

Dari nilai $\mathrm{OR}=7,846$ sehingga dapat disimpulkan bahwa responden yang tidak mengalami gizi kurang berpeluang 7,846 kali tidak mengalami ISPA dibandingkan dengan responden yang mengalami gizi kurang.Dari 6 balita dengan riwayat BBLR, sebanyak 5 balita $(5,2 \%)$ mengalami ISPA dan hanya $1(1 \%)$ balita yang tidak mengalami ISPA. Dari 91 balita yang tidak memiliki riwayat BBLR, sebanyak 40 balita $(41,2 \%)$ mengalami ISPA dan 51 balita $(52,6 \%)$ tidak mengalami ISPA. Dari hasil uji statistik, diketahui bahwa nilai $\mathrm{p}$ value $=0,093$, yang berarti $p>0,05$. Dengan demikian dapat kita simpulkan bahwa secara statistik tidak terdapat hubungan antara BBLR dengan kejadian ISPA pada Balita di Puskesmas Kecamatan Cilandak.

Dari 16 balita yang kurang mendapatkan imunisasi campak, sebanyak 12 balita $(12,4 \%)$ mengalami ISPA dan 4 balita $(4,1 \%)$ yang tidak mengalami ISPA. Dari 81 balita yang mendapatkan imunusisasi campak lengkap, sebanyak 33 balita (34\%) mengalami ISPA dan 48 balita (49,5\%) tidak mengalami ISPA.Dari hasil uji statistik, diketahui bahwa nilai $p$ value $=0,015$, yang berarti $p<0,05$. Dengan demikin dapat kita simpulkan bahwa secara statistik terdapat hubungan antara kurangnya imunisasi campak dengan kejadian ISPA pada Balita di Puskesmas Kecamatan Cilandak.

Dari nilai $\mathrm{OR}=4,364$ sehingga dapat disimpulkan bahwa responden yang mendapatkan imunisasi campak lengkap berpeluang 4,364 kali tidak mengalami ISPA dibandingkan dengan responden yang kurang mendapatkan imunisasi campak. Hasil analisis bivariat tersebut diringkas dalam bentuk tabel sebagai berikut. 
Tabel 2: Hubungan antara Gizi Kurang, BBLR dan Kurangnya Imunisasi Campak dengan Kejadian ISPA pada Balita di Puskesmas Cilandak Tahun 2018.

\begin{tabular}{|c|c|c|c|c|c|c|c|c|c|}
\hline \multirow{3}{*}{\multicolumn{2}{|c|}{ Variabel }} & \multicolumn{4}{|c|}{ ISPA } & \multicolumn{2}{|c|}{ Total } & \multirow{3}{*}{ OR 95\% CI } & \multirow{3}{*}{$P$ value } \\
\hline & & \multicolumn{2}{|c|}{ Ya } & \multicolumn{2}{|c|}{ Tidak } & \multirow{2}{*}{$\mathbf{F}$} & \multirow{2}{*}{$\%$} & & \\
\hline & & $\mathbf{F}$ & $\%$ & $\mathbf{F}$ & $\%$ & & & & \\
\hline \multicolumn{10}{|c|}{ Gizi Kurang } \\
\hline Ya & & 6 & 6,2 & 1 & 1 & 7 & 7,2 & 7,846 & \multirow{2}{*}{0,047} \\
\hline Tidak & & 39 & 40,2 & 51 & 52,6 & 90 & 92,8 & $(0,907-67,876)$ & \\
\hline \multicolumn{10}{|l|}{ BBLR } \\
\hline Ya & & 5 & 5,2 & 1 & 1 & 6 & 6,2 & & \multirow{2}{*}{0,093} \\
\hline Tidak & & 40 & 41,2 & 51 & 52,6 & 91 & 93,8 & & \\
\hline \multicolumn{10}{|c|}{ Kurang Imunisasi } \\
\hline $\begin{array}{l}\text { Campak } \\
\mathrm{Ya}\end{array}$ & & 12 & 124 & 4 & 41 & 16 & 165 & \multirow{2}{*}{$\begin{array}{l}4,364 \\
(1,294-14,711)\end{array}$} & \multirow{2}{*}{0,015} \\
\hline Tidak & & 33 & 34 & 48 & 49,5 & 81 & 83,5 & & \\
\hline
\end{tabular}

Sumber: Hasil analisis SPSS versi 21 Tahun 2018

\section{Pembahasan}

Penelitian ini merupakan penelitian kuantitatif yang menggunakan metode penelitian survey analitik dengan pendekatan Cross sectional, yaitu variabelvariabel penelitian diukur dan dikumpulkan dalam waktu yang bersamaan.

Hubungan Antara Gizi Kurang dengan Kejadian Infeksi Saluran Pernapasan Akut (ISPA) pada Balita di Puskesmas Kecamatan Cilandak Tahun 2018

Dari hasil uji statistik, diketahui bahwa nilai $\mathrm{p}$ value $=0,047$ yang berarti $\mathrm{p}<0,05$, sehingga menunjukkan hasil yang signifikan. Dengan demikian dapat kita simpulkan bahwa secara statistik terdapat hubungan antara gizi kurang dengan kejadian ISPA pada Balita di Puskesmas Kecamatan Cilandak.

Dari nilai OR $=7,846$ sehingga dapat disimpulkan bahwa responden yang tidak mengalami gizi kurang berpeluang 7,846 kali tidak mengalami ISPA dibandingkan dengan responden yang mengalami gizi kurang.

Gizi kurang adalah rendahnya kandungan zat gizi, baik mikro maupun makro di dalam tubuh seseorang. Menurut Calder (2000) pada kasus gizi kurang, individu akan lebih rentan terhadap infeksi akibat menurunnya kekebalan tubuh terhadap invasi. Aritonang (2007) menyatatakan Pertumbuhan yang baik dan status imunologi yang memadai akan menghasilkan tingkat kesehatan yang baik pula. Sebaliknya, pertumbuhan fisik yang terhambat biasanya disertai dengan status imunologi yang rendah sehingga balita mudah terkena penyakit. ${ }^{14.7}$

Hasil penelitian ini sesuai dengan hasil penelitian yang dilakukan oleh Hadiana (2013) tentang hubungan status gizi terhadap terjadinya
ISPA pada balita di Puskesmas Pajang Surakarta menyatakan bahwa ada hubungan antara status gizi terhadap terjadinya ISPA. Selain itu didapatkan nilai ratio prevalensi 27,5 yang artinya bahwa anak yang mengalami gizi kurang berisiko 27,5 kali untuk mengalami ISPA dibanding balita yang mengalami gizi baik.

Menurut asumsi penulis, ada hubungan antara gizi kurang dengan kejadian ISPA pada Balita. Pada Balita dengan status gizi kurang akan memiliki daya tahan tubuh yang lemah, sehingga akan memudahkan terjadinya infeksi, salah satunya adalah ISPA.

\section{Hubungan Antara Berat Badan Lahir Rendah (BBLR) dengan Kejadian Infeksi Saluran Pernapasan Akut (ISPA) pada Balita di Puskesmas Kecamatan Cilandak Tahun 2018}

Dari hasil uji statistik, diketahui bahwa nilai $\mathrm{p}$ value $=0,093$, yang berarti $\mathrm{p}>0,05$. Dengan demikian dapat kita simpulkan bahwa secara statistik tidak terdapat hubungan antara BBLR dengan kejadian ISPA pada Balita di Puskesmas Kecamatan Cilandak.

Berat badan lahir bayi (BBL) adalah berat badan bayi yang di timbang dalam waktu satu jam pertama setelah lahir. Berat Badan Lahir Rendah (BBLR) adalah bayi baru lahir yang berat badannya saat lahir kurang dari 2.500 gram. Pada bayi BBLR, pembentukan zat anti kekebalan kurang sempurna sehingga lebih mudah terkena penyakit infeksi terutama pneumonia dan sakit saluran pernapasan lainnya. ${ }^{15.9}$

Hasil penelitian ini tidak sesuai dengan hasil penelitian yang dilakukan oleh Husin (2014) tentang Hubungan BBL dan status imunisasi dengan kejadian ISPA pada balita di Puskesmas 
Wirobrajan Yogyakarta menyatakan bahwa ada Hasil Penelitian ini sesuai dengan hasil penelitian Sukmawati (2009) yang melakukan penelitian di Wilayah Kerja Puskesmas Tunikamaseang Kecamatan Bontoa Kabupaten Maros yang mendapatkan kesimpulan tidak adanya hubungan yang bermakna antara BBL dengan kejadian ISPA. ${ }^{16}$

Menurut asumsi penulis, tidak terdapat hubungan antara BBLR dengan kejadian ISPA pada Balita, hal ini disebabkan karena daya tahan tubuh balita terhadap infeksi lebih dipengaruhi oleh berat badan atau status gizi saat ini, bukan berat badan saat lahir. Selain itu, jika didukung oleh pemberian imunisasi yang lengkap, khususnya imunisasi campak anak tersebut tidak mudah terkena penyakit infeksi (ISPA).

\section{Hubungan Antara Kurangnya Imunisasi Campak dengan Kejadian Infeksi Saluran Pernapasan Akut (ISPA) pada Balita di Puskesmas Kecamatan Cilandak Tahun 2018}

Dari hasil uji statistik, diketahui bahwa nilai $\mathrm{p}$ value $=0,015$, yang berarti $\mathrm{p}<0,05$. Dengan demikin dapat kita simpulkan bahwa secara statistik terdapat hubungan antara kurangnya imunisasi campak dengan kejadian ISPA pada Balita di Puskesmas Kecamatan Cilandak.

Dari nilai $\mathrm{OR}=4,364$ sehingga dapat disimpulkan bahwa responden yang mendapatkan imunisasi campak lengkap berpeluang 4,364 kali tidak mengalami ISPA dibandingkan dengan responden yang kurang mendapatkan imunisasi campak.

Imunisasi campak merupakan imunisasi yang digunakan untuk mencegah terjadinya penyakit campak pada anak karena termasuk penyakit menular. Kandungan vaksin ini adalah virus yang dilemahkan. Campak dapat menyebabkan komplikasi yang serius, seperti radang paru (pneumonia), radang otak (ensefalitis), kebutaan, gizi buruk dan bahkan kematian. anak yang kurang mendapatkan imunisasi campak lebih berisiko terkena penyakit campak dan berisiko komplikasi radang paru (pneumonia) yang merupakan jenis ISPA. ${ }^{17.5}$

Hasil penelitian yang dilakukan oleh Lisdianti, Saparwati \& Choiriyah (2015) tentang hubungan status imunisasi terhadap kejadian ISPA pada anak usia Balita di wilayah kerja Puskesmas Pasir Putih Sampit Kalimantan Tengah menyatakan bahwa ada hubungan status imunisasi terhadap kejadian ISPA. Anak yang mendapatkan imunisasi lengkap lebih rendah mengalami kejadian ISPA hubungan berat badan lahir dengan kejadian ISPA.

daripada yang tidak mendapatkan imunisasi lengkap.

Menurut asumsi penulis, ada hubungan antara kurangnya imunisasi campak dengan kejadian ISPA pada balita karena balita yang kurang mendapatkan imunisasi campak akan lebih mudah terkena penyakit campak, akibatnya dapat menyebabkan komplikasi yang serius, salah satunya adalah ISPA.

\section{Kesimpulan}

Berdasarkan hasil penelitian mengenai "Hubungan Antara Gizi Kurang, Berat Badan Lahir Rendah (BBLR) dan Kurangnya Imunisasi Campak dengan Kejadian Infeksi Saluran Pernapasan Akut (ISPA) Pada Balita di Puskesmas Kecamatan Cilandak Tahun 2018", dapat diambil kesimpulan sebagai berikut:

1. Ada Hubungan Antara Gizi Kurang dengan Kejadian Infeksi Saluran Pernapasan Akut (ISPA) Pada Balita di Puskesmas Kecamatan Cilandak $(\mathrm{P}-$ Value $=0,004)$.

2. Tidak ada Hubungan Antara Berat Badan Lahir Rendah (BBLR) dengan Kejadian Infeksi Saluran Pernapasan Akut (ISPA) Pada Balita di Puskesmas Kecamatan Cilandak (P-Value = 0,093).

3. Ada Hubungan Antara Kurangnya Imunisasi Campak dengan Kejadian Infeksi Saluran Pernapasan Akut (ISPA) Pada Balita di Puskesmas Kecamatan Cilandak (P-Value = 0,015).

\section{Saran}

Bagi tenaga kesehatan diharapkan dapat mempertahankan promosi kesehatan yang telah ada agar dapat mengurangi angka kesakitan dan kematian balita yang disebabkan oleh penyakit ISPA.

Bagi Peneliti Selanjutnya diharapkan peneliti selajutnya dapat melakukan penelitian lanjutan dengan menggunakan pendekatan kualitatif sehingga dapat menjelaskan kepada responden tentang penegahan penyakit ISPA.

\section{Daftar Pustaka}

1. Masriadi. Epidemiologi Penyakit Menular. Depok: Raja Grafindo Persada; 2017.

2. Oktami R S. MTBS (Manajemen Terpadu Balita Sakit). Yogyakarta: Nuha Medika; 2017.

3. Kementerian Kesehatan RI. Pedoman Pengendalian Infeksi Saluran Pernapasan Akut. Jakarta: Kementerian Kesehatan RI; 2011. 
4. Pratiwi A \& Wahyun E G. Sistem Pakar Diagnosis ISPA pada Balita dengan Metode Certainty Factor. Seminar Nasional Informatika Medis (SNIMed) VII, p. 42; 2016.

5. Lisdianti, dkk. Hubungan Status Imunisasi Terhadap Kejadian ISPA Pada Anak Usia Balita di Wilayah Kerja Puskesmas Pasir Putih Sampit Kalimantan Tengah Ungaran. [Skripsi]. Program Studi Keperawatan Sekolah Tinggi Ilmu Kesehatan Ngudi Waluyo; 2015.

6. Kementerian Kesehatan RI. Riset Kesehatan Dasar 2013. Jakarta: Badan Penelitian dan Pengembangan Kesehatan Kementerian Kesehatan RI; 2013.

7. Hadiana S Y M. Hubungan Status Gizi Terhadap Terjadinya Infeksi Saluran Pernapasan Akut (ISPA) Pada Balita di Puskesmas Pajang Surakarta. [Skripsi]. Fakultas Kedokteran Universitas Muhammadiyah Surakarta; 2013.

8. World Health Organization. Epidemic-prone \& pandemic-prone acute respiratory diseases: Infection prevention \& control in health-care facilities. Jenewa : CSR; 2008.

9. Husin A. Hubungan Berat Badan Lahir dan Status Imunisasi dengan Kejadian ISPA pada Balita di Puskesmas Wirobrajan Yogyakarta. [Skripsi]. Program Studi Diploma IV Bidan Pendidik Sekolah Tinggi Ilmu Kesehatan Aisyiyah; 2014.

10. Lapau B. Metode Penelitian Kesehatan: Metode Ilmiah Penulisan Skripsi, Tesis dan Disertasi. Jakarta: Yayasan Pustaka Obor Indonesia; 2013.

11. Notoatmodjo S. Metodologi Penelitian Kesehatan. Jakarta : Rineka Cipta; 2010.

12. Sugiyono. Metode Penelitian Manajemen. Bandung: Alfabeta; 2014.

13. Bersal. Pengolahan dan Analisa Data-1 Menggunakan SPSS. Depok : Departemen Biostatistika - FKMUI; 2010.

14. Muhith \& Siyoto. Pendidikan Keperawatan Gerontik. Yogyakarta: Andi Offset; 2016.

15. Kemenkes RI. Profil Kesehatan Indonesia Tahun 2014. Jakarta: Sekretariat Jenderal Kementerian Kesehatan RI; 2015.

16. Sukmawati. Hubungan Status Gizi, Berat Badan Lahir, Imunisasi dengan Kejadian ISPA pada Balita di Wilayah Kerja Puskesmas Tunikamaseang Kecamatan Bontoa Kabupaten Maros. [Skripsi]. Poltekkes Makassar; 2009.

17. Peraturan Menteri Kesesehatan RI No.42 Tahun 2013. 